\title{
An Exploratory Analysis of the Role of Higher Educationin Developing Knowledge Economy in Pakistan
}

\author{
Dr. Uzma Munawar \\ Assistant professor Department of Education \\ The Government Sadiq College Women University Bahawalpur \\ druzmamunawar@gmail.com \\ Dr. Muhammad Ayub Buzdar \\ Assistant professor Department of Education \\ Government College University Faisalabad \\ ayubbuzdar@gmail.com
}

\begin{abstract}
Knowledge is the key for growth and development of any country. Historically, only those countries succeeded and advanced which based their economies on knowledge. Higher education authorities in Pakistan are trying to promote the notion of knowledge economy in the country. This paper provides an exploratory analysis of various factors and indicators which disclose relationship between the higher education products and economic indicators of the country. There are four main pillars of knowledge economy i.e. education and training, information infrastructure, economic incentive \&institutional regime, and innovation systems. Progress on different economic indicators is analyzed and concluded that investment in higher education is not supporting a shift in the nature of economy in Pakistan. Spontaneous and temporary steps may further deteriorate the situation. The paper urges on an overall restructuring of higher education policy and procedure of its implementation in contemporary economic and financial scenario of the country and globe.
\end{abstract}

Keywords: Higher Education; Innovation; Research and Development; H Index

\section{1: Introduction}

Knowledge is the procurement of realities, data, and aptitudes through experience or instruction; the hypothetical or viable comprehension of a subject. Knowledge can be verifiable or unequivocal; it tends to be pretty much formal or deliberate(Oxford Dictionary, 2015). Knowledge is being utilized to quicken and propel the development procedure. When useful for a wide range of development, it turns into a primary asset for capital generation and work openings. The utilization of knowledge is as of now all around perceived to be one of the essential establishments of progress in the general economy. The term Knowledge Economy (KE) has been instituted to uncover this improved hugeness of information (Mustafa, 2015).The concept of knowledge economy 
has transformed the traditional concept of knowledge from a philosophical and pure academic reference to an economic connotation. Under this emerging concept, knowledge is not a mere belief and state of mind but a set of experiences learned and reflected through human practices (Jensen, 2012; Turner, 2012). World Bank accepted four pillars of knowledge economy including economic and institutional regime, education and skill of population, information infrastructure, and innovation system(WorldBank, 2015).

Developed and emerging global economies have concentrated to win advancements in these four pillars and pursued a paradigm shift in their economic frontiers (de la PazMarín, Gutiérrez, \& Hervás-Martínez, 2015). Literature demonstrates that a number of countries moved very quickly towards knowledge-based economy whereas, many economies were very slow in this process. Knowledge production and dissemination mechanisms highly contribute for success in such endeavors. These mechanisms generally operate under higher education systems and are aimed to influence, promote, and comprehensively nurture all four pillars of the knowledge-based economies.

Countries with emerging economies vary in their efforts for developing and transfiguring innovative and knowledge economy promoter educational systems(Weber, 2011).Higher education system in Pakistan remained under high criticism due to not meeting global tasks of skill development, technological advancement and knowledge economy formation (Bano \& Taylor, 2015; Lodhi \& Zaman, 2012). We in this article reviewed the growth of higher education in Pakistan concentrating on its contribution in realizing the task of knowledge-based economy in the country. We analyzed Pakistani efforts comparing its performance against different economic and educational indicators with SAARC (South Asian Association for Regional Cooperation) countries.

\section{2:Nature of Pakistani Economy}

The economy of Pakistan has been brimming with good and bad times. At the hour of freedom, Pakistan needed to pull off its economy on small resources. Pakistan had 30 million individuals with per capita income of US\$100, presently we have 180 million individuals with per capita income more than US\$ 100 (Mustafa, 2015).Pakistani economy remained dependent on agricultural products especially that have export potentials. Many indicators demonstrate that agriculture sector positively contributes in economic growth of the country. Pakistan is the $3^{\text {rd }}$ largest exporter of rice. More than 3 million tons of rice is exported, it is the $5^{\text {th }}$ major textile producing country in the world. The crop economy provides raw material to the industrial sector, which increases employment opportunities and promotes the country exports (Afzal, 2006; Henneberry \& Khan, 2000). Composition of Pakistan economy shows that agriculture sector is sharing more $20-25 \%$ of the GDP since 2008-09. Agriculture and services including transport and communication are demonstrating positive growth since 2008-09. Otherwise remaining sectors of Pakistan economy including industry, large-scale manufacturing, construction, wholesale and retail trade and finance and insurance were demonstrating negative growth rate in 2008-09. The situation, however, changed in four years and the country 
demonstrated positive growth rate in all reported sectors of the economy(National Bank of Pakistan, 2014).A regional comparison demonstrates that the export of goods and services provided 13\% share in the GDP of Pakistan in 2013 whereas, for Bhutan, India and Bangladesh these shares were $40 \%, 25 \%$ and $20 \%$ respectively. The imports of goods and services of Pakistan are $20 \%$ of its GDP whereas, for Bhutan, India and Bangladesh these shares are 63\%, 28\% and 27\% respectively (WorldBank, 2014b). The share of imports of goods and services in Pakistan GDP is 53\% higher than the share of exports of Goods and services. However, this ratio is $57 \%, 12 \%$ and $35 \%$ for Bhutan, India and Bangladesh.

Less share of export of services and goods and a widening gap between the exports and imports unveil the fragile conditions of Pakistan economy that is also reflected in many international economic reports. Pakistani exports of fabricated products were higher than the joined exports Thailand, Malaysia, Indonesia, and Philippines. South Korea copied Pakistan in its multiyear improvement plan during 1960. The nationalization of significant private ventures during Bhutto's system antagonistically affected the monetary development of the nation. After that the development design stayed languid. For instance, the World Bank forecasting for the years 2014, 2015, and 2016 situates Pakistan among the South Asian countries with lowest GDP growth rates(WorldBank, 2014a). It is estimated that Bhutan, India and Sri Lanka would perform better than Pakistan in next two years. Pakistan, on the other hand, has observed a stagnant condition in the shares of three major sectors of Pakistan's economy (agricultural, industrial, and services) since 2008-09(NationalBankofPakistan, 2014)and the situation may persist in near future (WorldBank, 2014a).

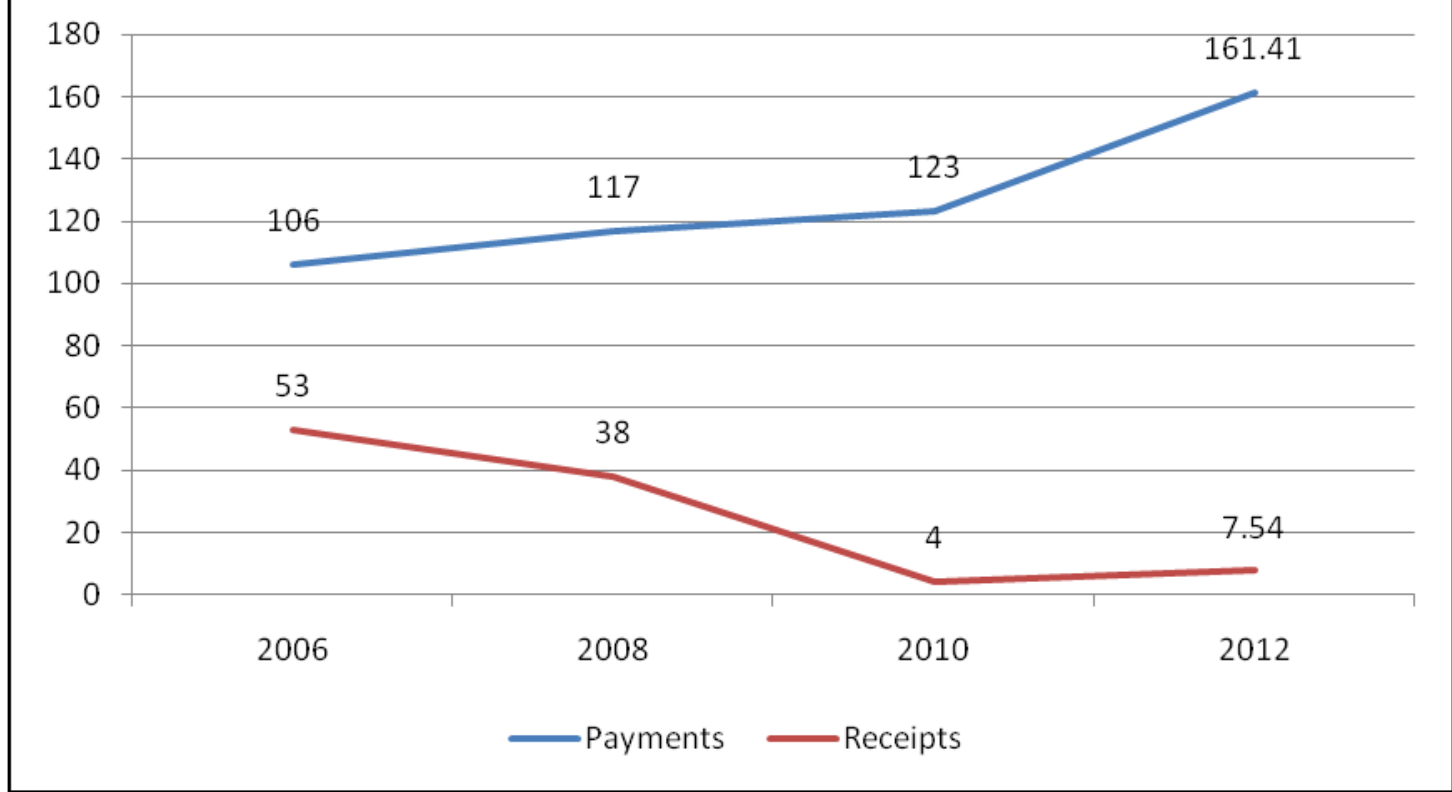


Figure 1: Charges for the use of intellectual property in payments and receipts between residents and nonresidents for the authorized use of proprietary rights and for the use, through licensing agreements, of produced originals or prototypes and related rights. Data are in millions of current U.S. dollars.

Source:WorldBank, 2014b

Comparison of the gaps between shares of export and import of goods and services in GDPs of different countries strengthens the idea that this gap reduces in the countries that have developed knowledge-based economies. Another major indicator of economic output of knowledge production is gaining property rights. Data show that gaps between payments and receipts of property rights have widened in previous years in Pakistan (see figure 1). It reflects a deteriorating condition of intellectual and technical advancements, which are closely linked with economic stagnation in the country. In next section of this paper, we try to examine the reasons of this economic recession in the context of knowledge economy, research, innovation and higher education. It is important to investigate how Pakistan's economy is utilizing knowledge and innovation as capital and economy revolutionizer, and to what extent higher education in Pakistan has potential to turn the economy from traditional to a knowledge-based track.

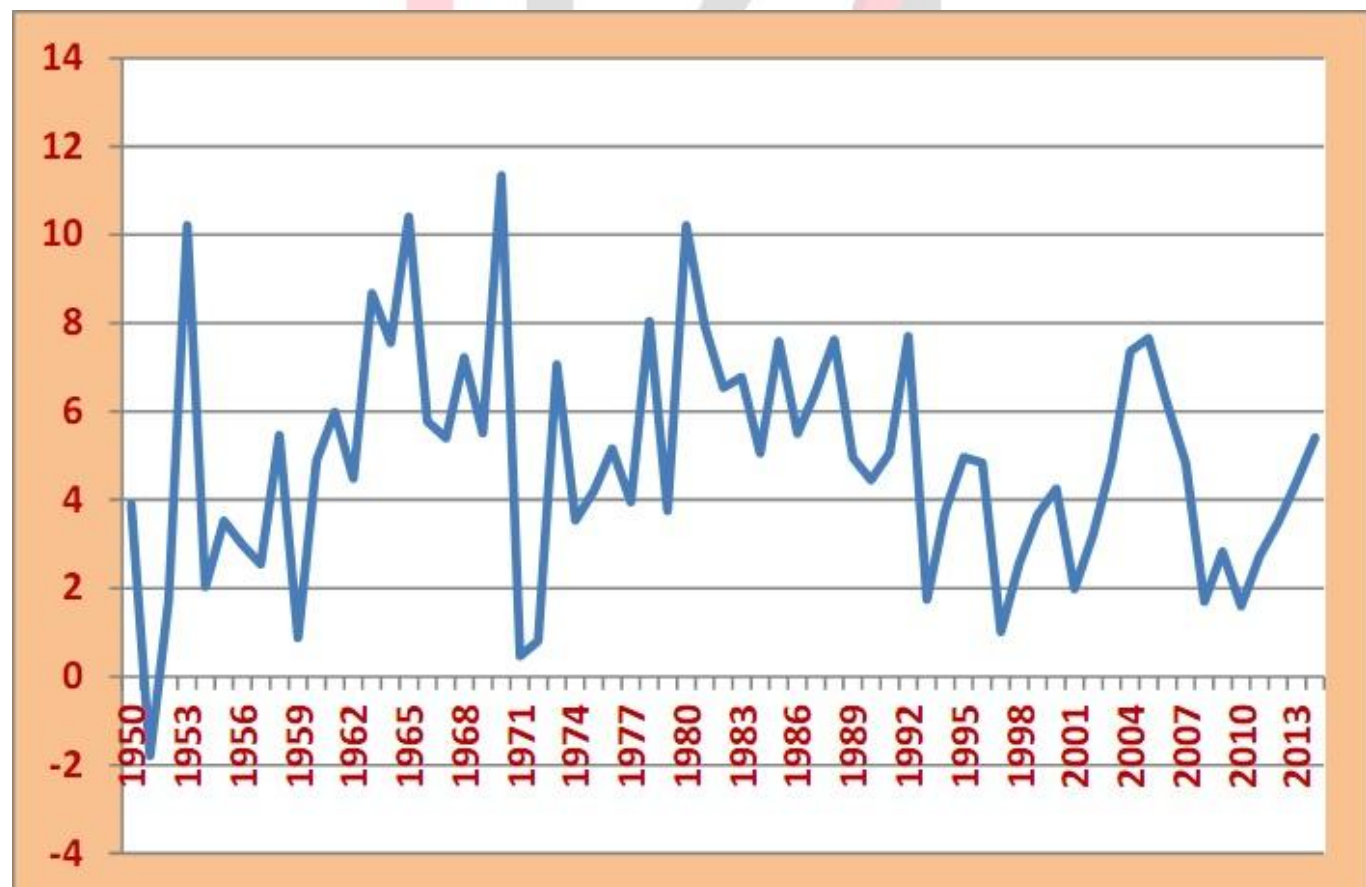

Figure 2: Pakistan's Economic Growth (1950 -2013) from Different Economic Surveys Source:Government of Pakistan, 2015; Mustafa, 2016

A well managed and impartial system of higher education (HE) that endorses quality learning as an outcome of both teaching and research is vital for success. It is widely 
acknowledged that HE contributes significantly to the development of a country. The developed economies understood much earlier the fact that individuals with HE have an edge over their counterparts (Haider \& Dilshad, 2015). The Government of Pakistan has understood the hugeness of making Pakistan's economy as knowledge-based economy. The initial step was taken by building up Higher Education Commission\| (HEC), which is a free, self-sufficient, and unavoidably settled establishment for essential financing, managing, controlling, and certifying the advanced education endeavors in Pakistan (Mustafa, 2015). The commission is liable for detailing advanced education strategy and quality confirmation to fulfill the global guidelines just as giving authorizing scholastic degrees, development of new foundations, and elevating of existing organizations in Pakistan.

New worldwide patterns in $\mathrm{HE}$ are changing its conventional structure and shape. Presently advanced education is increasingly modern and esteem added when contrasted with the old occasions. All over the world, rapid growth and global changes in $\mathrm{HE}$ involved academic research collaboration, increase in international student mobility, internationalization, offshore mobility of $\mathrm{HE}$ and shift towards vocational and technical education. The increasing number of international student's mobility in tertiary education created a new competition among the higher education institutions(Haider \& Dilshad, 2015). It is not a new phenomenon but the speed of its growth has been exceptional in the last two decades. According to OECD Report (2010), the student's international mobility in OECD countries has more than doubled in the past 20 years.

\section{3:Pakistan's Preparedness for Knowledge Economy}

Knowledge economy establishes its foundation on academic and technological innovation and research. Global Innovation Index (GII) 2014 situates Pakistan in second last position in the SAARC region. India gains highest position in the GII securing $76^{\text {th }}$ position out of 143 countries scoring 33.7/100 points(Dutta, Lanvin, \& Wunch-Vincent, 2014). Pakistan is on $134^{\text {th }}$ position with the score of 24.0/100. Only Nepal is lagging behind Pakistan with $136^{\text {th }}$ positionin the SAARC region (table 1). The GII provides ranking of 143 countries in which Pakistan stands on $134^{\text {th }}$ position. Only nine countries in the report perform lesser than Pakistan. 


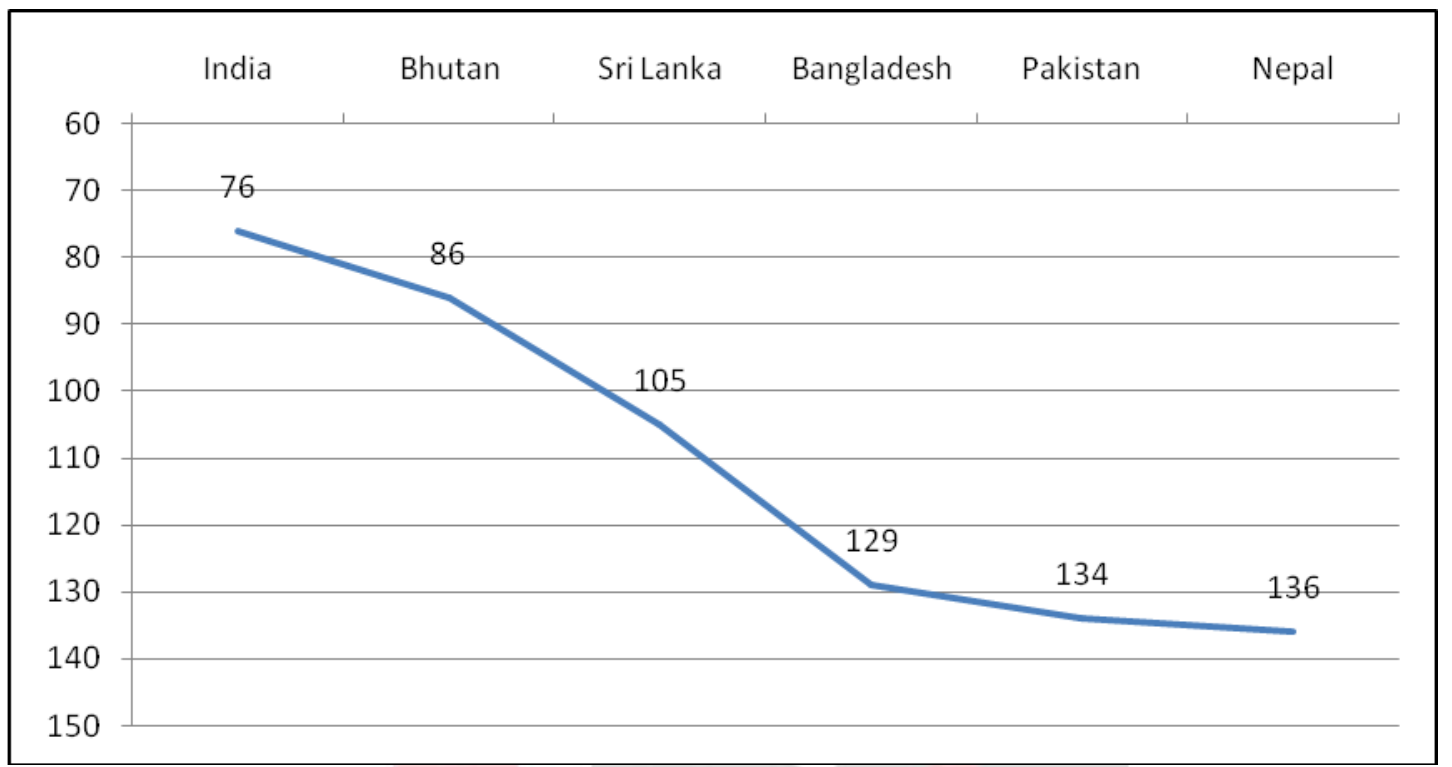

Figure 3: Comparison of SAARC countries' ranking out of 143 countries on Global Innovation Index. Source: Global Innovation Index 2014, published by World Intellectual Property Organization (WIPO), editors: Dutta, et al. (2014).

The concept of innovation is highly related with knowledge production and absorption. Use of knowledge as capital generator has revolutionized higher educationsystems globally. Pakistan has the youth profit, its greater part of the populace comprises of youngsters and it is a chance to reap it, through information, skills and abilities(Sathar, Royan, \&Bongaarts, 2013). Investment in human capital and research is considered vital for constructing knowledge base economy(Turner, 2012). Deteriorate and static condition of Pakistan economy and a lower performance in GII may be linked with the lesser investmentin human capital and research.Consequently,Pakistan demonstrates lower ranking $\left(139^{\text {th }}\right.$ position out of 143 countries $)$ in human capital and research index with the score of only 09.8/100 (See table 1).

Three areas of human capital and research are projected in the index in which Pakistan performance is comparatively better in research and development securing $68^{\text {th }}$ position. Pakistan score in research and development indicator is $9.8 / 100$ whereas, India gets $31^{\text {st }}$ position with the score of 32 . It shows that despite a comparatively better position in global ranking Pakistan's score is significantly low in research and development, which produces problematic consequences for the country's economy. The worsened situation in school and tertiary education has further exploited the results of lesser investment in research and development. Pakistan ranks on $141^{\text {st }}$ and $124^{\text {th }}$ position in the indicators of school and tertiary education, respectivelysecuring 10.7 and 8.9 scores out of 100 . These scores are lowest in the SAARC region.

Lesser ranking in research and development and deteriorate positioning in school and tertiary education in Pakistan produced complex results in knowledge and technology 
output index. Pakistan scored 21.9 points in knowledge and technology output index whereas, India's score was 32.2 against this indicator. Sri Lanka and Bangladesh also demonstrated better position than Pakistan. The scores of Pakistan against the three indicators of knowledge and technology outputs i.e. knowledge creation, knowledge impact and knowledge diffusion are 10.0, 29.7 and 26.0 respectively.

Table 1. Comparison ofvalues/scores (0-100) obtained by SAARC countries on different indicators of Global Innovation Index

\begin{tabular}{lcccccc}
\hline Indicators & India & Bhutan & Sri Lanka & Bangladesh & Pakistan & Nepal \\
\hline Global Innovation Index & 33.7 & 31.8 & 29.0 & 24.4 & 24.0 & 23.8 \\
\hline Human Capital \& Research & 22.7 & 17.0 & 17.1 & 14.1 & 09.8 & 15.5 \\
Education (School) & 24.7 & 42.3 & 29.9 & 20.6 & 10.7 & 31.5 \\
Tertiary Education & 11.7 & 08.8 & 18.2 & 15.0 & 08.9 & 12.6 \\
Research \& Development & 32.0 & 00.0 & 03.4 & 05.1 & 09.8 & 02.8 \\
\hline Knowledge \& Technology Outputs & 32.2 & 02.8 & 26.5 & 22.2 & 21.9 & 11.2 \\
Knowledge Creation & 18.4 & 05.1 & 07.1 & 06.1 & 10.0 & 11.4 \\
Knowledge Impact & 34.1 & 02.5 & 34.9 & 29.9 & 29.7 & 02.4 \\
Knowledge Diffusion & 44.1 & 00.7 & 37.5 & 30.5 & 26.0 & 19.9 \\
\hline Business Sophistication & 28.0 & 29.3 & 19.8 & 14.9 & 19.3 & 31.3 \\
Knowledge Workers & 25.0 & 31.1 & 23.6 & 11.8 & 17.5 & 38.3 \\
Innovation Linkages & 38.9 & 43.4 & 21.9 & 25.5 & 20.1 & 28.0 \\
Knowledge Absorption & 20.2 & 13.3 & 13.9 & 07.3 & 20.3 & 27.6 \\
\hline \multicolumn{2}{c}{ Source: Global Innovation Index 2014, published by World Intellectual Property Organization (WIPO), } \\
& editors: Dutta, et al. (2014). & & &
\end{tabular}

India, Bhutan, Sri Lanka and Bangladesh performed better than Pakistan in human capital and research index. The countries are also higher than Pakistan in knowledge and technology outputs except Bhutan. Though Pakistan's ranking is comparatively higher in research and development index with $68^{\text {th }}$ position and second in the SAARC region yet its score against the indicator (9.8) is very low than India (32.0)and other countries of the region. One result of comparatively higher ranking in research and development may the relatively higher ranking of Pakistan in knowledge creation indicator in the SAARC region. Pakistan demonstrates $79^{\text {th }}$ position in knowledge creation index securing $3^{\text {rd }}$ position in the SAARC region. However, the scores Pakistan obtained in research and development and knowledge creation indicators are significantly low. 


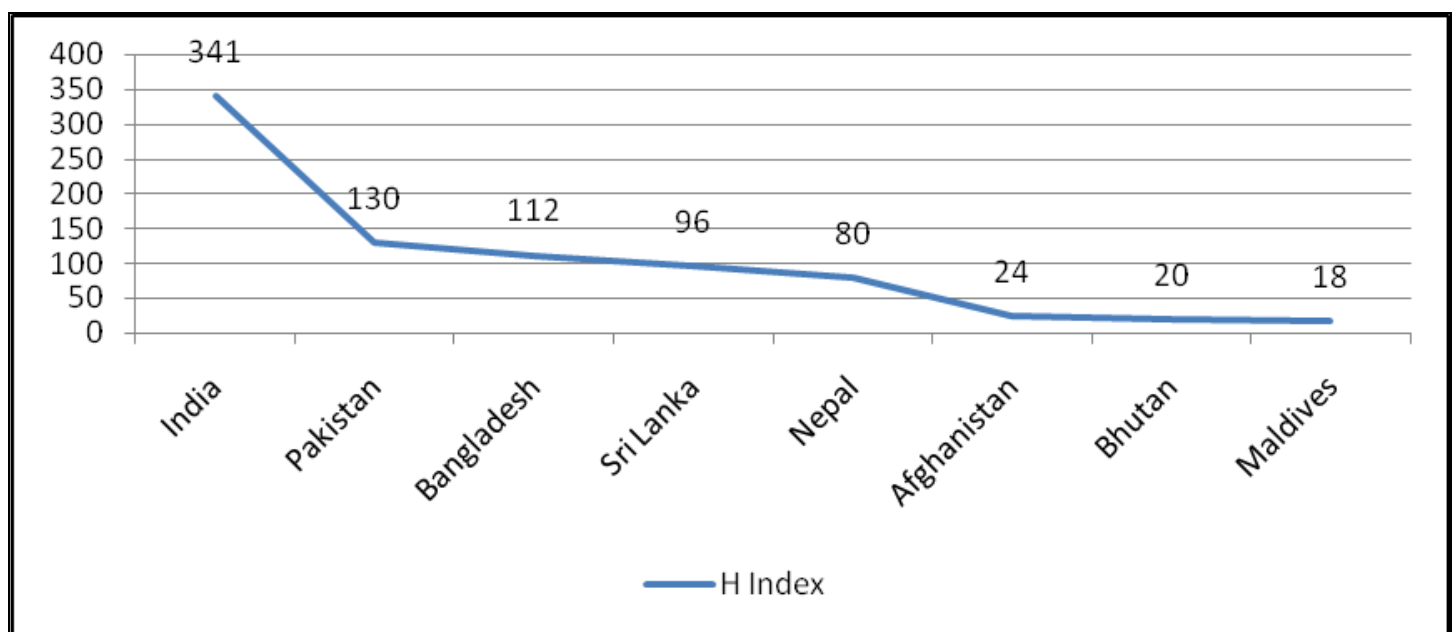

Figure 4: Comparison of H Index (2013) obtained by SAARC countries. Source: The SC Imago Journal \& Country Ranking based on Scopus database. URL: http://www.scimagojr.com/countryrank.

The gap between knowledge creation in India and Pakistan is also visible in $\mathrm{H}$ Index. India scored 341 in H Index for the year 2013 whereas, Pakistan's score was 130 (See figure 4). $\mathrm{H}$ Index shows the numbers of article (from the country), that receive $\mathrm{H}$ citations. Pakistan and India score 10.0 and 18.4 on knowledge creation indicator in global innovation index respectively. Citations and citable documents contribute in knowledge creation activities of the country. Though Pakistan is performing comparatively better than other SAARC countries (except India) in $\mathrm{H}$ index and knowledge creation indicator yet it demonstrates weak performance in business sophistication indicator, which is a place where acquired and created knowledge is translated into economic practices.

Knowledge and technology outputs and knowledge creation should be reflected in the business sophistication to achieve the target of progressive knowledge economy. Data demonstrate that Pakistan's ranking is not stable in the business sophistication index. Pakistan is on $133^{\text {rd }}$ position out of 143 countries in business sophistication index that is second last in the SAARC region scoring 19.3/100 points. The GII presents three sub indicators of business sophistication including knowledge workers, innovation linkages and knowledge absorption. Pakistan performance is comparatively better in the knowledge absorption indicator in which it secured $2^{\text {nd }}$ position in the SAARC countries and $99^{\text {th }}$ position in the world gaining 20.3 scores. India is not far behind gaining $100^{\text {th }}$ position in world ranking with 20.2 scores. Linkage of innovation with market business is among the essentials of knowledge economy. Pakistan's score is 20.3 that is lowest in the SAARC region.

A small economy Bhutan is performing very well in the region obtaining 43.4 scores under this indicator. India's score is 38.9 and Nepal is showing the score of 28.0 against innovation linkages indicator. Pakistan's weaker performance in this area has worsened 
the neglected impacts of weak position in human capital and research index. Similarly, Pakistan is on second last position in the region with $129^{\text {th }}$ position in world in the category of knowledge workers scoring 17.5/100 points. Anotherindicator ofknowledgebased economy is numbers of patent granted by the country to its residents. Table 2 provides detail data of patent applications (a country received) and patent grants(a country granted) in the year 2012. It also shows how many patent applications were filed abroad. There is a wide gap between the Indian and Pakistani data.

Table 2. Comparison of patent applications and patent grants awarded in SAARC countries in 2012

\begin{tabular}{|l|c|c|c|c|c|c|}
\hline \multirow{2}{*}{ Country } & \multicolumn{3}{|c|}{ Patent Applications } & \multicolumn{3}{c|}{ Patent Grants } \\
\cline { 2 - 7 } & Residents & Non-Residents & Abroad & Residents & Non-Residents & Abroad \\
\hline India & 9553 & 34402 & 8620 & 722 & 3606 & 2866 \\
\hline Pakistan & 96 & 798 & 16 & 13 & 299 & 13 \\
\hline Bangladesh & 67 & 287 & 04 & - & - & 01 \\
\hline Sri Lanka & - & - & 33 & - & - & 06 \\
\hline
\end{tabular}

Source: World Intellectual Property Organization (WIPO) database, last updated 03/2014. URL: http://www.wipo.int/ipstats/en/statistics/country_profile/

Resident $=$ domestic filings; Non-resident $=$ filings coming in from other countries; Abroad = filings going out to other countries

India received 9553 patent applications from the residents of India and 34402 from the non-residents. Indian residents also filed 8620 patent applications abroad. Pakistan, on the other hand, received 96 patent applications from Pakistani residents and 798 from the non-residents. Only 16 patent applications were filed abroad by Pakistani citizens. There is a gap between patent grants in Pakistan and India. India granted 722 patents to Indian citizens whereas Pakistan granted only 13 patents to Pakistan's residents. The 2866 Indians received patents abroad whereas only 13 Pakistani residents received patents abroad. The performance of other SAARC countries is more pathetic. Nepal granted 02 patents to its residents. Sri Lanka, Afghanistan and Bangladesh received 06, 02, and 01 patent abroad. Pakistan's weak performance against business sophistication indicator, its sub indicators and patent applications \& grants question the application of higher education products in national economy.

Currently, 160 HEC recognized public and private sector universities and degree awarding institutes are functioning across the country. A recent report of World Economic Forum ranks 148 countries on global competitiveness. Though the report has its foundations on Executive Opinions Survey carrying out globally yet its importance cannot be undermined in this era of emerging knowledge economies. The global competitiveness report demonstrates that India, Bhutan and Sri Lanka are in comparatively better position than Pakistan in many indicators including quality of the education system. Pakistan is lagging behind India, Bhutan and Sri Lanka in availability of research and training services(Schwab, 2014). Economic role of higher education 
demands a knowledge-based linkage between university and finance producers e.g. agriculture, industry and business. Ultimate results of application of knowledge in industry are uptake and registration of patents, as well as receipts of intellectual property rights, which demonstrates a significant shift in the composition of economy.We in Pakistan are facing a static situationin the economy in this regard and Gross Development Products (GDP) is fundamentally relying on agriculture and services sectors only.

\section{4: Conclusions}

There is a significant extension, numerous chances and pathways for developing Asia all in all and Pakistan specifically into knowledge-based economies. By the center of this century, Asia may be contributing half of the worldwide yield, exchange, and speculation, while likewise appreciating boundless riches. Pakistan predominantly keeps an agrarian economy producing agricultural products that are directly exportable or provided to industrial sector as raw materials. However, the emerge of knowledge-based economies has aroused the need of intervening innovation and knowledge capital into traditional agrarian and industrial economies. More than half share of GDP of Pakistan is occupied by services sector. Agricultural and industrial sectors share in rest of the economy. This ratio is majorly stagnant from several years. The average GDP growth rate as well as forecast for 2014, 2015 and 2016 situates Pakistan in the countries who demonstrate reasonably lower GDP growth.

We attempted to trace out the reasons of this economic recession assessing the country's performance against basic components of knowledge economy. We found that Pakistan is second last country in the SAARC region in GII securing $134^{\text {th }}$ position out of 143 global economies. Pakistan's performance is lowest against the indicator of human capital and research in the region. Though Pakistan performed comparatively better in research and development indicator securing second position in the region yet the gap between first ranked India (32 points) and second ranked Pakistan (9.8 points) in the region questioned the commitment of Pakistani higher education sector with research and development. A wide gap between the values of H-Index for India (341) and Pakistan (130) also explore this issue.

Similar gap is also visible in patents grants of India (4328) and Pakistan (312) in the year 2012. Share of the exports of goods and services in GDP was significantly lower for Pakistan (13\%) than Bhutan (40\%), India (25\%) and Bangladesh (20\%) in the year 2013. Share of the imports of goods and services are 53\% higher than the share of exports of Goods and servicesin Pakistan GDP. This ratio is very low for India(12\%) and Bangladesh (35\%). Gap between the payments and receipts of intellectual property rights is also widening. Pakistani residents (individual and companies) received \$7.54 million of intellectual property rights in 2012 whereas, payments of Pakistani individuals and companies for the said period were \$161.41million. It demonstrates that Pakistani residents (including academia, researchers, scientists, technologists etc.) are not integrating and using their achievements for promoting national economy. 
We concluded in this paper that not only the structure of higher education and research is weak in the country but the situation in applying knowledge outcome in practical economy is also unsatisfactory. Global competitiveness report 2014 ranked Pakistan lower thanSri Lanka, India, and Bhutan in the indicator of quality of education system. Innovation linkages of Pakistan are also in lowest position in the SAARC region. This paper recommends a paradigm shift in the educational preferences especially at higher level in Pakistan. Universities and research institutes should initiate more ventures for research and development. A mechanism that focuses on introduction, application and integration of higher education inventions and innovations in industry and economy is also recommended. Higher education system, in this regard, can revolutionize the traditional concept of economy to a knowledge-based economy in Pakistan. Instead of above-mentioned points, Pakistan has various positive viewpoints in its economy in spite of requirements. These include: its key area; versatile economy, which is faced with psychological warfare, clashes, cataclysmic events, complex political advances; yet it is as yet enduring and developing in spite of the considerable number of hindrances.

\section{References}

Afzal, M. (2006). Causality between exports, world income and economic growth in Pakistan. International Economic Journal, 20(1), 63-77. doi: 10.1080/10168730500515399

Bano, S., \& Taylor, J. (2015). Universities and the knowledge-based economy: perceptions from a developing country. Higher Education Research \& Development, 34(2), 242-255. doi: 10.1080/07294360.2014.956696

De la Paz-Marín, M., Gutiérrez, P. A., \& Hervás-Martínez, C. (2015). Classification of countries' progress toward a knowledge economy based on machine learning classification techniques. Expert Systems with Applications, 42(1), 562-572. doi: 10.1016/j.eswa.2014.08.008

Dutta, S., Lanvin, B., \& Wunch-Vincent, S. (2014). The Global Innovation Index 2014: The human factor in innovation. Geneva, Switzerland: World Intellectual Property Organization.

Government of Pakistan (2015). Pakistan Economic Survey 2014-15.Ministry of Finance, Government of Pakistan.

Haider, S. Z., \& Dilshad, M. (2015). Higher Education and Global Development: A Cross Cultural Qualitative Study in Pakistan. Higher Education for the future, 2(2), 175193. doi: $10.1177 / 2347631114558185$

Henneberry, S. R., \& Khan, M. E. (2000). An Analysis of the Linkage Between Agricultural Exports and Economic Growth in Pakistan. Journal of International Food \& Agribusiness Marketing, 10(4), 13-29. doi: 10.1300/J047v10n04_02

Jensen, H. S. (2012). The Changing Role of Knowledge in the Knowledge Economy: Concepts of Knowledge and Knowledge Management. In K. I. Westeren (Ed.), 
Foundations of the Knowledge Economy: Innovation, Learning and Clusters. Cheltenham, UK: Edward Elgar.

Lodhi, S., \& Zaman, K. (2012). Perspectives of the knowledge-based economy on the educational sector: spotlight on Pakistan. Knowledge Management for Development Journal, 8(2-3), 128-140. doi: 10.1080/19474199.2012.712049

Mustafa, U. (2015). Appropriate Development Strategy and Role of Private Sector. Roadmap for Economic Growth of Pakistan. IslamabadPolicy Research Institute (IPRI), Islamabad

Mustafa, U. (2016).An Overview of Pakistan's Economy: Current Use of Four Pillars of a Knowledge Economy and its Further Promotion. Building Knowledge-Based Economy in Pakistan: Learning from bestPractices.

NationalBankofPakistan. (2014). Economic Indicators Pakistan. In. Karachi: National Bank of Pakistan.

Organization for Economic Co-operation and Development (2010). Education at a glance 2010: OECD Indicators. Retrieved 18July 2019, from http://www.oecd.org/education/skills-beyond-school/45926093.pdf

OxfordDictionary (2015).Oxford advanced Learner's Dictionary.(AmericanEnglish). Viewed in

October 2015.http://www.oxforddictionaries.com/us/definition/learner/knowledge

Sathar, Z., Royan, R., \& Bongaarts, J. (2013). Capturing the demographic dividend in Pakistan. Population Council.One DagHammarskjold Plaza. New York, NY 10017 USA. PopulationCouncil, House No. 7, Street No. 62, Section F-6/3, Islamabad,Pakistan. http://www.popcouncil.org.

Schwab, K. (2014). The Global Competitiveness Report 2013-2014. Geneva: World Economic Forum.

Turner, D. A. (2012). Higher education: Centre stage or in the wings of the knowledge economy-A review essay. International Journal of Educational Development, 32(6), 835-837. doi:10.1016/j.ijedudev.2012.02.006

Weber, A. S. (2011). The role of education in knowledge economies in developing countries. Procedia-Social and Behavioral Sciences, 15, 2589-2594. doi: 10.1016/j.sbspro.2011.04.151

WorldBank. (2014a). Global Economic Prospects. Washington, DC: The World Bank. WorldBank. (2014b). World Development Indicators. Washington, DC: The World Bank. World Bank.(2015). Knowledge for Development (K4D).Washington, DC: The World Bank. 